\title{
COMPARISON OF PRODUCTIVITY OF KRANMAN BISON 10000 FORWARDER IN STANDS HARVESTED WITH HARVESTER AND CHAINSAW
}

\author{
Santa KALEJA, Latvian State Forest Research Institute "Silava", 111 Rigas str., Salaspils, LV-2169 Latvia; $\underline{\text { santa.kaleja@ silava.lv }}$ \\ (corresponding author) \\ Agris ZIMELIS, Latvian State Forest Research Institute "Silava", 111 Rigas str., Salaspils, LV-2169 Latvia; Latvian State Forest \\ Research Institute "Silava".ı, 111 Rigas str., Salaspils, LV-2169 Latvia, andis.lazdins@ @ilava.lv \\ Andis Lazdins, Latvian State Forest Research Institute "Silava", 111 Rigas str., Salaspils, LV-2169 Latvia; andis.lazdins@ silava.lv \\ Per Olof Johansson, Gillesby AB, Sweden; peo@gillesby.se
}

\begin{abstract}
The aim of this study is to investigate potential uses of Kranman Bison 10000 6WD forwarder in stands, where roundwood is extracted with a chainsaw and Vimek 404 T5 harvester in normal and difficult forwarding conditions. Productivity of Kranman forwarder was compared with medium-sized John Deere 810 forwarder under normal conditions. In total 230 loads were forwarded during the study, including 63 loads from areas, harvested with a chainsaw, and 167 loads from areas, harvested with Vimek 404 harvester. The average forwarded load is $2.0 \mathrm{~m}^{3}$ (the maximum load is $2.5 \mathrm{~m}^{3}$ therefore the average load capacity is $80 \%$ ). In average 33 minutes of productive work time were spent by forwarding one load (the proportion of productive working time is $94 \%$ from total engine hours of the machine). The average length of forwarding road in trials is $286 \mathrm{~m}$. In normal conditions forwarding of $1 \mathrm{~m}^{3}$ of roundwood extracted with a chainsaw takes 15 minutes of productive working time, but in difficult forwarding conditions the time consumption increases by $13 \%$. The average forwarder fuel consumption is $1.8 \mathrm{~L}$ per hour. Accordingly, $0.8 \mathrm{~L}$ of fuel are consumed to forward $1 \mathrm{~m}^{3}$ roundwood. In comparison, John Deere 810 under similar conditions consumed $1.6 \mathrm{~L}$ fuel to forward $1 \mathrm{~m}^{3}$ roundwood. Study results prove that the best application of Kranman Bison 10000 is forwarding small stands or individual trees logged with a chainsaw. Forwarder can work on soils with low bearing capacity, however productivity can be significantly reduced by stumps and uneven terrain.
\end{abstract}

Keywords: Kranman Bison 10000, productivity, thinning

\section{INTRODUCTION}

Roundwood forwarding is one of forestry operations and it is necessary to assess how it is affected by various factors. According to literature, there are several factors affecting work productivity such as harvesting method, location and concentration of roundwood piles, the average load size, forwarding distance and forwarding conditions (Sirén, 2003; Nurminen, Korpunen, \& Uusitalo, 2006; Väätäinen, Ala-Fossi, Nuutinen, \& Röser, 2006; Sakai, Nordfjell, Suadicani, Talbot, \& Bøllehuus, 2008; Sarmulis \& Saveljevs, 2015; Strandgard, Mitchell, \& Acuna, 2017)国. One of solutions how to make this mechanization more efficient is choose of suitable harvesting system which let increase work productivity (Talbot, Nordfjell, \& Suadicani, 2003; Väätäinen et al., 2006) ?. Thinning, especially pre-commercial thinning, is done manually using chainsaw or using harvesters (Laitila, Asikainen, \& Nuutinen, 2007). Nowadays amount of thinnings accomplished by harvesters increase rapidly, but still, how significant this tendency affects forwarding productivity, is actual question (Väätäinen et al., 2006; Laitila et al., 2007) ?? One of the factors affecting forwarding productivity is roundwood location in the stand. Location and size of roundwood piles in mechanized and manual thinning are different (Nurminen et al., 2006; Laitila et al., 2007) ?. According to several studies, changing the average forwarding distance by only a few tens of meters, forwarding productivity decreases significantly but forwarding costs increases (Sarmulis \& Saveljevs, 2015; Strandgard et al., 2017)国, which reflects the prime cost calculation. Bearing capacity of soil in the harvest site and in the forwarding road outside the harvest site has a significant impact on forwarder movement, but this factor can be adapted. When making forwarding roads, forest site type should be taken into account. Increased fertilizations reduce the bearing capacity of soil (Uusitalo, 2010; Sarmulis \& Saveljevs, 2015)]. According to the guidelines of JSC "Latvia's State Forest" there are four types of forwarding conditions in state forests. Forwarding conditions in forest types Cladinoso-callunosa, Vacciniosa, Myrtillosa and Hylocomiosa are characterized as good, with good bearing capacity of soil, forwarding can be done for all seasons. Forwarding conditions in forest types Oxalidosa, Aegipodiosa, Callunoso-

Copyright (C) 2017 The Authors. Published by Aleksandras Stulginskis University. This is an open-access article distributed under the terms of the Creative Commons Attribution License (CC-BY 4.0), which permits unrestricted use, distribution, and reproduction in any medium, provided the original author and source are credited. 
sphagnosa, Vaccinioso-sphagnosa, Myrtilloso-sphagnosa, Callunosa mel., and Vacciniosa mel. are characterized as average, with moderate bearing capacity of soil. Forwarding is possible throughout the whole year, when tracks are mounted. Forwarding conditions are bad in forest types Myrtillosoi-polytrichosa, Drypteriosa, Myrtillosa mel., Mercurialosa mel., Callunosa turf. Mel., Vacciniosa turf. Mel., Myrtillosa turf. Mel. and Oxalidosa turf. Mel., characterized by weak bearing capacity of soil. Forwarding is possible only by mounting tracks and putting low-grade roundwood into forwarding roads and forwarding roads outside a stand to improve the bearing capacity. Forwarding conditions in forest types Sphagnosa, Caricoso-phragmitosa, Dryopterioso-caricosa and Filipendulosa are characterized as extreme with very low bearing capacity of soil. Forwarding can be done only when forwarders are equipped with tracks on the rear and front axle or soil is frozen or dried out (Liepa et al., 2014; AS "Latvijas valsts meži," 2015; Sarmulis \& Saveljevs, 2015)]. Productivity of forwarding is affected also by technical parameters of forwarder (Sarmulis \& Saveljevs, 2015; Uusitalo, 2010)]. In the thinning usually medium- size forwarder weighing 11 to 13 tonnes with 6 and 8 wheels were used. The average load capacity for such forwarder is 10 to 12 tonnes (Laitila, 2008)? In order to make thinning of small dimension trees more efficient new solutions to reduce production costs are being sought. One of the solutions might be the use of small- size forwarders with price of base machine is relatively lower thus affecting the production costs. The aim of this study is to investigate potential uses of Kranman Bison 10000 6WD forwarder in thinning, where roundwood is extracted with a chainsaw and Vimek 404 T5 harvester working in normal and difficult forwarding conditions and to determine productivity, average load size and forwarding costs.

\section{MATERIAL AND METHODS}

In this study forwarding productivity data were obtained in stands, where roundwood was prepared with a chainsaw and Vimek 404 T5 harvester, on normal and difficult forwarding conditions. "Normal forwarding conditions" mean that soil bearing capacity is good and moist areas are not crossed, whereas "difficult forwarding conditions" mean that bearing capacity of soil is moderate or low, moist areas are crossed and it is necessary to strengthen strip roads with harvesting residues. The study was conducted in stands (25.5 ha) representing fertile Hylocomiosa (44\% of the total area or $11.6 \mathrm{ha}$ ), Myrtillosa mel. (27\% of the total area or $7.2 \mathrm{ha}$ ), Myrtilloso-sphagnosa (22\% of the total area or $5.8 \mathrm{ha}$ ) and Myrtillosa turf.mel. (7\% of the total area or 1.9 ha) site types in central part of Latvia nearby Jelgava in forests of Forest Research Station territory. The average number of trees in different stands before thinning ranged from 974 to 2050 trees per hectare. According to the measurement, the average tree diameter (at breast height) of dominant species ranged from 9.8 to $15.3 \mathrm{~cm}$, average height from 13.4 to $17.3 \mathrm{~m}$ but average stock value ranged from 137 to $216 \mathrm{~m}^{3}$ per ha ${ }^{-1}$, respectively. Forwarding was carried out with Kranman Bison 10000 6WD 6-wheeled forwarder. Technical parameters of forwarder are provided in Table 2.

Table 1. Technical parameters of forwarder

\begin{tabular}{|l|l|l|}
\hline Nr. & Indicators & Numerical values \\
\hline 1. & operating weight & $1520 \mathrm{~kg}$ \\
\hline 2. & engine output & $2.800 \mathrm{rpm} . \mathrm{min}^{-1}$ \\
\hline 3. & power & $24 \mathrm{hp}$ \\
\hline 4. & maximum speed & $14 \mathrm{~km} \mathrm{ha}^{-1}$ \\
\hline 4. & standard speed & $7 \mathrm{~km} \mathrm{ha}^{-1}$ \\
\hline 6. & loading capacity & $2500 \mathrm{~kg}$ \\
\hline 7. & total length & $6.10 \mathrm{~m}$ \\
\hline 8. & width & $1.55 \mathrm{~m}$ \\
\hline 9. & crane max. reach & $3.3 \mathrm{~m}$ \\
\hline
\end{tabular}

Time study of forwarding was carried out manually by continuous time method using hand-held data logger Allegro CX. In the time study one work cycle can include up to 15 work elements (Table 2.). Total working time ( $\left.\mathrm{E}_{0}\right)$ of forwarding includes all work elements but productive working time $\left(E_{15}\right)$ includes all work elements except "delays".

Forwarding operations were implemented in July - September, 2016. Detailed work studies were done by forwarding $455 \mathrm{~m}^{3}$ round wood. Most of the forwarded roundwood $\left(335 \mathrm{~m}^{3}\right.$ or $\left.74 \%\right)$ was prepared with Vimek $404 \mathrm{~T} 5$ harvester and the rest $\left(120 \mathrm{~m}^{3}\right.$ or $\left.26 \%\right)$ was prepared with a chainsaw. Prime cost calculation of forwarding was done according to calculation models used in similar studies carried out previously (Ackerman et al., 2014; Kaleja, Lazdinšs, \& Zimelis, 2014; Lazdinš̌, 2014) ?. Operator costs are the sum of salaries and other operator costs (social charges and other benefits) (Ackerman et al., 2014) ?? In cost calculation was assumed that forwarder is employed 8 hours a day. If roundwood was prepared with a chainsaw, in calculation was assumed that team of 4 people were working, 3 of them were working with chainsaw and 1 is working on forwarder. If roundwood was prepared with Vimek 404 T5 harvester in calculation was assumed that team of 3 people were working, of them 2 were working on harvester and 1 was working on forwarder. The number of employees was determined on the basis of average productivity. Machine costs are costs for fuel, lubricant, maintenance, repair and other consumables (Ackerman et al., 2014) [?. Logging service provider data obtained in detailed cost monitoring were used in prime cost 
calculation. Estimated profit is 5\%. The average work productivity for each unit of machinery were used for cost calculation. During experiment the average diameter of trees logged with a chain saw and Vimek harvester were determined $\mathrm{D}_{1.3} 9 \mathrm{~cm}$ and $\mathrm{D}_{1.3} 11 \mathrm{~cm}$ respectively. The average productivity used in calculation for a chainsaw was $1.5 \mathrm{~m}^{3}$ but for Vimek harvester $9.9 \mathrm{~m}^{3}$ in productive hour. Following average indicators of forwarder were received during experiment and used in cost calculation: average forwarder load $2.0 \mathrm{~m}^{3}$, average productive time spent on loading (17 min.) and on unloading (6 min.), average speed of forwarder 44 m per min. ${ }^{-1}$, average forwarding distance in one direction $254 \mathrm{~m}$. Road transport distance was assumed to be the same $(50 \mathrm{~km})$. In order to determine the significance level of data T-test and Wilcoxon signet-rank test were used.

Table 2. Work elements of forwarding operations

\begin{tabular}{|c|c|c|}
\hline $\begin{array}{l}\text { Number of work } \\
\text { element }\end{array}$ & Work elements & Description of work element \\
\hline 1 & driving unloaded & $\begin{array}{l}\text { Starts when forwarder leaves the landing area and ends when the forwarder stops } \\
\text { at the first loading stop. }\end{array}$ \\
\hline 2 & reach during loading & $\begin{array}{l}\text { Starts with grapple loader movement to start loading and ends when the grapple } \\
\text { loader reach the pile of roundwood. }\end{array}$ \\
\hline 3 & gripped during loading & Starts with reaching of roundwood pile and ends with creating of grapple load. \\
\hline 4 & loading & $\begin{array}{l}\text { Starts with lifting the grapple load and ends when the grapple load is laid on the } \\
\text { bunk. }\end{array}$ \\
\hline 5 & sorting load & Sorting the roundwood in the bunk. \\
\hline 6 & moving during loading & $\begin{array}{l}\text { Movement between roundwood piles with no grapple loader movement. Starts } \\
\text { when the operator prepares move to the next loading stop and ends when the } \\
\text { forwarder stops at the next loading stop. }\end{array}$ \\
\hline 7 & road packing & $\begin{array}{l}\text { Starts with grapple loader movement to piles of branches to insert or remove them } \\
\text { from forwarding roads and ends when the operator starts to move the grapple load } \\
\text { in order to other work operation. }\end{array}$ \\
\hline 8 & driving loaded & $\begin{array}{l}\text { Starts when the operator starts to move to the landing area with a load and ends } \\
\text { when wheels cease to rotate the operator starts to move the grapple loader. }\end{array}$ \\
\hline 9 & reach during unloading & $\begin{array}{l}\text { Starts with grapple loader movement to start unloading and ends when the grapple } \\
\text { loader reach the pile of roundwood in forwarder's bunk. }\end{array}$ \\
\hline 10 & gripped during unloading & $\begin{array}{l}\text { Starts with commencement of crane movement, with an empty grapple, } \\
\text { Towards the forwarders bunk and ends with creating of grapple load in } \\
\text { forwarder's bunk. }\end{array}$ \\
\hline 11 & unloading & $\begin{array}{l}\text { Starts with lifting the grapple load and ends when the grapple load is lifted onto } \\
\text { the pile. }\end{array}$ \\
\hline 12 & sorting roundwood yard & Sorting roundwood on the landing pile. \\
\hline 13 & moving during unloading & $\begin{array}{l}\text { Movement between the piles at the landing area. Starts when the operator prepares } \\
\text { move to the next pile and ends when the forwarder stops at the next pile. }\end{array}$ \\
\hline 14 & other operations & $\begin{array}{l}\text { Other activity in forwarding work (planing of work, lifting of fallen roundwood } \\
\text { etc.) } \\
\text { The reason of the activity was recorded. }\end{array}$ \\
\hline 15 & delays & $\begin{array}{l}\text { Time not related to productive forwarding work, e.g. personal breaks, repairing or } \\
\text { maintenance of forwarder, phone calls. The reason of the activity was recorded. } \\
\text { Delay time longer than } 15 \text { minutes. }\end{array}$ \\
\hline
\end{tabular}

\section{RESULTS AND DISCUSSIONS}

Within the study Kranman Bison 10000 6WD forwarder had worked in total 250 hours. In total 230 loads were forwarded during the study, including 63 loads from areas, harvested with a chainsaw, and 167 loads from areas, harvested with Vimek $404 \mathrm{~T} 5$ harvester. The average forwarded load was $2.0 \mathrm{~m}^{3}$ (the maximum load was $2.5 \mathrm{~m}^{3}$ therefore the average load capacity was 80\%). The average forwarding time of 1 load was 33 minutes of productive time (the proportion of productive time is $94 \%$ from total engine hours of the machine). Roundwood forwarding from areas, harvested with a chainsaw were spent 32 min. per load but from areas, harvested with Vimek 404 T5 harvester were spent 33 min. per load. On average loading and unloading of one load takes accordingly 16.3 and $5.8 \mathrm{~min}$. When forwarding of average load logged by both harvesting methods was compared, no statistically significant differences were found in total time consumption. On average $1 \mathrm{~m}^{3}$ forwarding takes 16.5 minutes of productive working time. In comparison of average productive time for forwarding of $1 \mathrm{~m}^{3}$ according to the harvesting methods, statistically significant differences have not been identified. Analysing the work elements (productive time) (Figure 1), statistically significant differences during loading $(\mathrm{p}=0.00003<0.05)$ were observed in working time consumption of roundwood gripping, with a chainsaw prepared round wood it was $27 \%$ less than with harvester prepared round wood. Differences $(\mathrm{p}=0.001<0.05)$ were observed in the inserting of roundwood in the load (loading), with a chainsaw prepared 
roundwood it was $13 \%$ less, which is explained with more convenient placement of round wood piles. Also, there are differences $(\mathrm{p}=0.01<0.05)$ in working time consumption of roundwood gripping during unloading, with a chainsaw prepared round wood it was $10 \%$ less. Significant differences $(\mathrm{p}=0.008<0.05)$ were found by unloading of roundwood prepared with harvester. Time, which was spent for this work element was $7 \%$ less that could be explained with layout of roundwood in load. Driving during unload was $36 \%$ less with chainsaw prepared round wood $(\mathrm{p}=0.02<0.05)$.

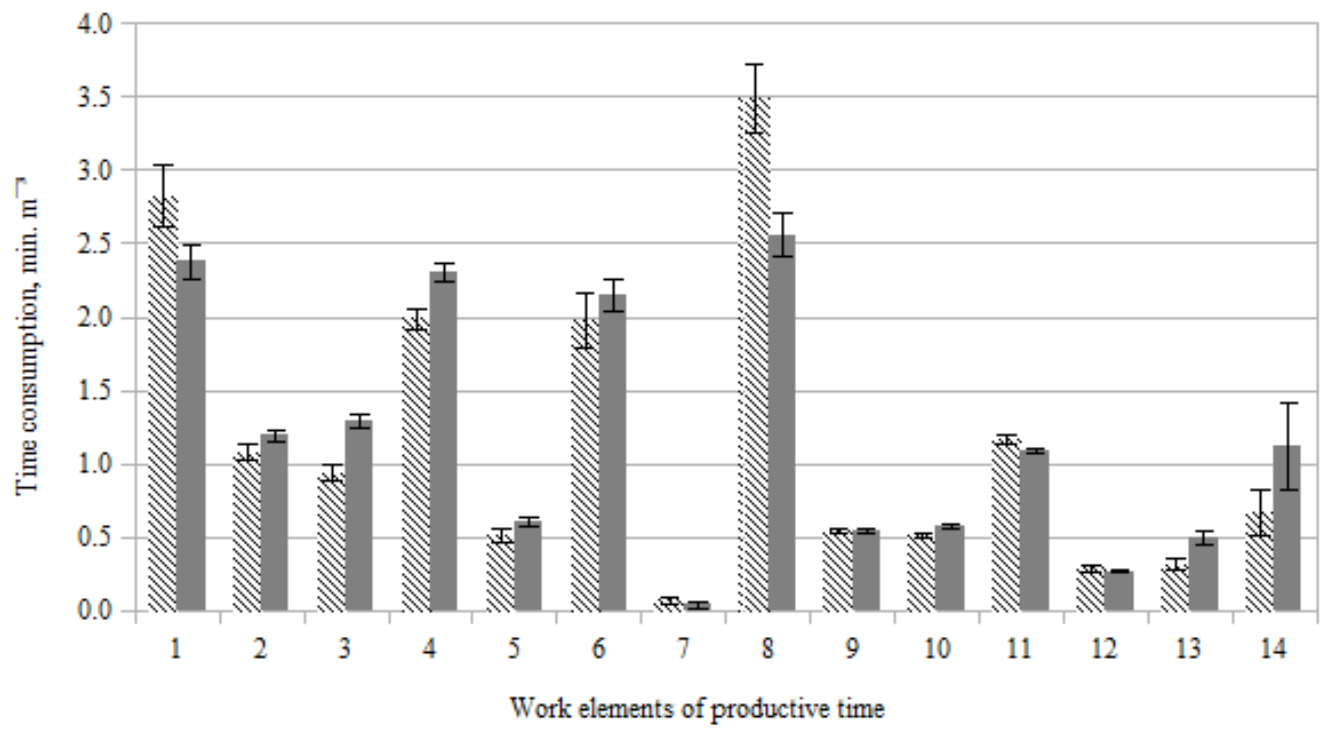

NChainsaw Vimek 404 T5 harvester

Figure 1. Distribution of work elements of productive time in forwarding of $1 \mathrm{~m}^{3}$ of roundwood depending on harvesting method

Productive working time in normal and difficult forwarding conditions are respectively $95 \%$ and $98 \%$ of the total working time. Average speed of forwarder was $55.3 \mathrm{~m} \mathrm{~min}^{-1}$, respectively in normal forwarding conditions $63.6 \mathrm{~m} \mathrm{~min}^{-1}$ (average load $1.88 \mathrm{~m}^{3}$ ) and difficult forwarding conditions $46.9 \mathrm{~m} \mathrm{min.-1}$ (average load $1.94 \mathrm{~m}^{3}$ ). The speed of forwarder in normal forwarding conditions was considerably higher than in difficult forwarding conditions. For roundwood forwarding from areas with normal forwarding conditions $28.9 \mathrm{~min}$. per load were spent but from areas with difficult forwarding conditions $32.1 \mathrm{~min}$. per load were spent On average loading and unloading of one load in normal and difficult forwarding conditions takes accordingly 13.7 and 5.3 min. and 13.5 and 5.4 min. respectively. The differences are not statistically significant. In normal forwarding conditions the average length of forwarding distance was $417 \mathrm{~m}$, but in difficult forwarding conditions $235 \mathrm{~m}$.

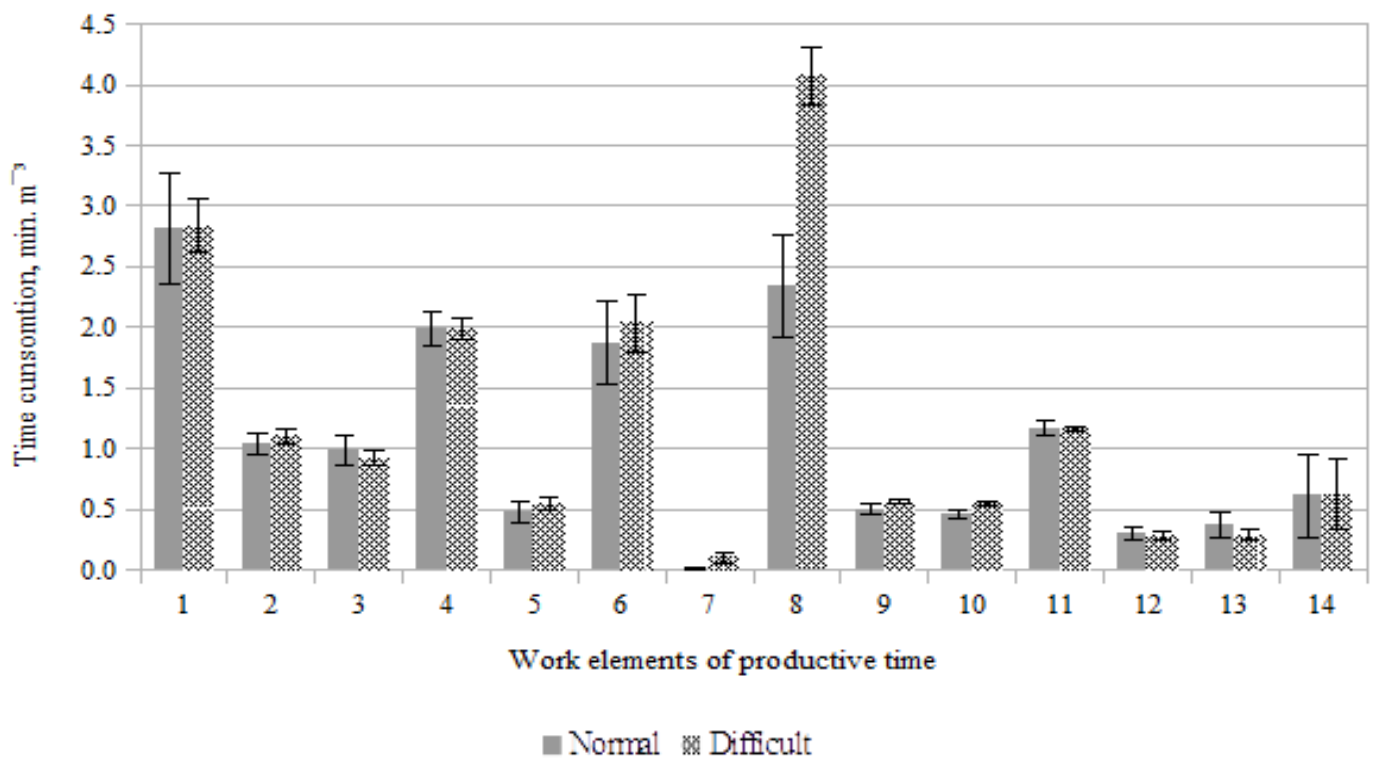

Figure 2. Distribution of work elements of productive time in forwarding of $1 \mathrm{~m}^{3}$ chainsaw prepared roundwood depending on forwarding conditions

Analysing the forwarding productive work time depending on forwarding conditions (Figure 2), even though in difficult forwarding conditions for forwarding of $1 \mathrm{~m}^{3}$ round wood were spent more productive work time than in normal conditions, differences are not statistically significant. Statistically significant differences $(p=0.0007<0.05)$ 
observed in forwarder driving speed, however contrary to the expectations in difficult forwarding conditions the average forwarder speed was higher. This is due to a longer flat stage in forwarding distance, which allowed significantly increase the average speed. Analysing the work elements statistically significant differences in travel time for the loaded forwarder ( $\mathrm{p}=0.005<0.05$, in normal conditions are spent $42 \%$ less time) and moving during unloading $(\mathrm{p}=0.02<0.05$, in normal conditions are spent $8 \%$ less time) can be observed in the operations, which are related with movement (driving time makes up an average $30 \%$ of total time), but these differences can be explained with length of forwarding distance and location of pails, therefore movement elements are not included in order to assess statistical differences of harvesting methods. The study confirms that forwarding distance affects productivity of forwarder significant, this has been proven in several studies (Laitila et al., 2007; Strandgard et al., 2017).

In comparison of medium-sized forwarder John Deere 810 (Lazdinšs, 2014)] and small-sized forwarder Kranman Bison 10000 6WD in normal forwarding conditions (Table 3), productivity of Kranman Bison 10000 6WD forwarder in loading and unloading of $1 \mathrm{~m}^{3}$ of roundwood are $12 \%$ and $41 \%$ less, respectively. The average load size of John Deere 810 is four times higher than average load size of Kranman Bison 10000 6WD. In forwarding of one load using small-sized forwarder Kranman Bison 10000 6WD, twice less productive time was spent. The average driving speed of John Deere 810 forwarder is $11 \%$ higher. The average fuel consumption of forwarding $1 \mathrm{~m}^{3}$ of roundwood which has a significant influence on the cost of production Kranman Bison 10000 6WD is twice smaller than medium-sized forwarder.

Table 3. Comparison of the average indicators of medium-sized and small-sized forwarder under normal forwarding conditions

\begin{tabular}{|c|c|c|c|c|c|c|c|c|c|c|c|c|}
\hline \multirow[b]{2}{*}{ 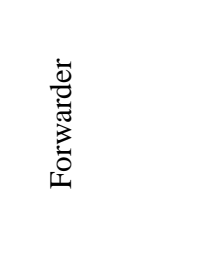 } & \multicolumn{3}{|c|}{ Productivity, $\mathrm{m}^{3}$ per $\mathrm{E}_{15}$} & \multirow{2}{*}{ 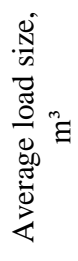 } & \multirow{2}{*}{ 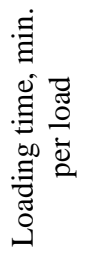 } & \multirow[b]{2}{*}{ 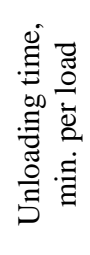 } & \multirow[b]{2}{*}{ 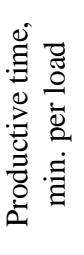 } & \multirow[b]{2}{*}{ 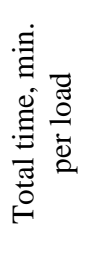 } & \multirow[b]{2}{*}{ 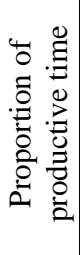 } & \multirow{2}{*}{ 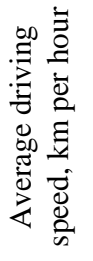 } & \multirow{2}{*}{ 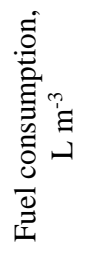 } & \multirow{2}{*}{ 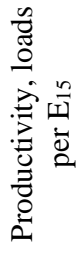 } \\
\hline & 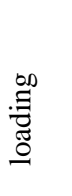 & 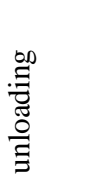 & ఫేّ & & & & & & & & & \\
\hline $\begin{array}{l}\text { Kranman Bison } \\
10000\end{array}$ & 8.6 & 21.5 & 4.3 & 1.9 & 14 & 5 & 29 & 30 & $98 \%$ & 2.8 & 0.8 & 2.0 \\
\hline John Deere 810 & 9.8 & 36.4 & 7.0 & 7.9 & 48 & 13 & 68 & 69 & $99 \%$ & 3.1 & 1.6 & 0.9 \\
\hline
\end{tabular}

Prim cost calculation shows (Table 4), that if harvesting is carried out with a chainsaw and forwarding with Kranman Bison $100006 \mathrm{WD}$, the prim cost of roundwood is $23.6 € \mathrm{~m}^{-3}$, including $18.6 € \mathrm{~m}^{-3}$ harvesting and forwarding. If harvesting is carried out with Vimek 404 T5 harvester and forwarding with Kranman Bison 10000 6WD, the prim cost of round wood is $20.7 € \mathrm{~m}^{-3}$, including $16.2 € \mathrm{~m}^{-3}$ harvesting and forwarding. If harvesting is carried out with a chainsaw and forwarding with John Deere 810, the prim cost of roundwood is $23.7 € \mathrm{~m}^{-3}$, including $18.7 € \mathrm{~m}^{-3}$ harvesting and forwarding. If harvesting is carried out with Vimek 404 T5 harvester and forwarding with John Deere 810, the prim cost of round wood is $20.5 € \mathrm{~m}^{-3}$, including $15.9 € \mathrm{~m}^{-3}$ harvesting and forwarding. However, the use of a medium-sized forwarder, if thinning is done with Vimek 404 T5 harvester, is possible just theoretically because of thinning technology (Lazdiñš, 2014; Zimelis, Lazdiņš, \& Prindulis, 2015; Zimelis, Lazdiņš, \& Spalva, 2016)?.

Table 4. Prime cots calculation of different harvesting systems

\begin{tabular}{|c|c|c|c|c|c|}
\hline Parameters & Cainsaw & $\begin{array}{l}\text { Vimek } \\
404 \mathrm{~T} 5\end{array}$ & $\begin{array}{c}\text { Kranman Bison } \\
100006 \mathrm{WD}\end{array}$ & John Deere 810 & Road transport \\
\hline \multicolumn{6}{|l|}{ Equipment unit costs, $€$ annual } \\
\hline Investment & $€ 506$ & $€ 35263$ & $€ 7822$ & $€ 34954$ & $€ 15206$ \\
\hline Operator costs & $€ 26720$ & $€ 41911$ & $€ 13136$ & $€ 26273$ & $€ 14536$ \\
\hline Machine costs & $€ 4595$ & $€ 90229$ & $€ 6337$ & $€ 44786$ & $€ 31207$ \\
\hline Estimated profit & $€ 1591$ & $€ 8370$ & $€ 1365$ & $€ 5301$ & $€ 3047$ \\
\hline In total, $€$ annual & $€ 33412$ & $€ 175774$ & $€ 28660$ & $€ 111313$ & $€ 63997$ \\
\hline \multicolumn{6}{|l|}{ Productivity } \\
\hline Roundwood (with bark), $\mathrm{m}^{3}$ per $\mathrm{E}_{15}$ & 1.5 & 9.9 & 3.4 & 6.7 & 10.1 \\
\hline \multicolumn{6}{|l|}{ Total annual amount of production } \\
\hline Roundwood (with bark), $\mathrm{m}^{3}$ annual ${ }^{-1}$ & 3944 & 28479 & 3670 & 14399 & 14070 \\
\hline Roundwood (without bark), $\mathrm{m}^{3}$ annual ${ }^{-1}$ & 3315 & 23477 & 3307 & 12972 & 12676 \\
\hline Bark and other forest residues, $\mathrm{m}^{3}$ annual ${ }^{-1}$ & 365 & 2583 & 364 & 1427 & 1394 \\
\hline \multicolumn{6}{|l|}{ Prime cost } \\
\hline Total amount of production, $€ \mathrm{~m}^{-3}$ & $€ 8.47$ & $€ 6.17$ & $€ 7.81$ & $€ 7.73$ & $€ 4.55$ \\
\hline Roundwood, $€ \mathrm{~m}^{-3}$ & $€ 10.08$ & $€ 7.49$ & $€ 8.67$ & $€ 8.58$ & $€ 5.05$ \\
\hline
\end{tabular}




\section{CONCLUSIONS}

1. Summary of the main forwarding productivity indicators depending on work method shows that the unload productivity with a chainsaw prepared round wood was $7 \mathrm{~m}^{3}$ but with harvester prepared round wood was $8 \mathrm{~m}^{3}$ in productive hour. Loading productivity was respectively 21 and $20 \mathrm{~m}^{3}$ in productive hour, driving speed 59.0 and $43.5 \mathrm{~m} \mathrm{min.}^{-1}$.

2. Summary of the main forwarding productivity indicators depending on forwarding conditions shows that the unload productivity in different forwarding conditions was $8 \mathrm{~m}^{3}$ but in normal forwarding conditions was $9 \mathrm{~m}^{3}$ in productive hour. Loading productivity was respectively 21 and $21 \mathrm{~m}^{3}$ in productive hour, driving speed 63.6 and $46.9 \mathrm{~m} \mathrm{min.}^{-1}$

3. Study results prove that the best application of Kranman Bison 10000 is forwarding small stands or individual trees, when logging with a chainsaw. Forwarder can work on soils with weak bearing capacity, however productivity can be significantly hindered by stumps and uneven terrain.

4. Prime cost of a Kranman Bison $100006 \mathrm{WD}$ working hour with a 5\% rate of return is $20 €$ (prime cost of a productive working hour is $24 €$ ). Round wood forwarding prime cost, when working 1172 productive hours annually, is $7.14 \mathrm{~m}^{-3}$. Average costs of forwarder are 28.7 thousand $€$ annually, including personal costs $46 \%$.

5. If harvesting is carried out with Vimek $404 \mathrm{~T} 5$ harvester and forwarding with Kranman Bison $100006 \mathrm{WD}$, the prim cost of roundwood is $2.89 € \mathrm{~m}^{-3}$ less than if harvesting is carried out with a chainsaw and forwarding with Kranman Bison 10000 6WD.

\section{ACKNOWLEDGEMENT}

The study is implemented within the scope of the memorandum between LSFRI Silava and Joint stock Company "Latvia state forests" from 11.10.2011.

\section{REFERENCES}

1. Ackerman, P., Belbo, H., Eliasson, L., de Jong, A., Lazdins, A., Lyons, J. 2014. The COST model for calculation of forest operations costs. International Journal of Forest Engineering, Vol. 25(1), pp. 75-81. https://doi.org/10.1080/14942119.2014.903711

2. AS "Latvijas valsts meži." 2015. Vadlīnijas pievešanas apstākḷu noteikšanai (The guidelines for determination of forwarding conditions). [In Latvian]

3. Kaleja, S., Lazdinš, A., Zimelis, A. 2014. Impact of assortments' structure on harvesting productivity and costs of pre-commercial thinning. Research for Rural Development, Vol. 2, pp. 83-89.

4. Laitila, J. 2008. Harvesting Technology and the Cost of Fuel Chips from Early Thinnings. Silva Fennica, Vol. 42(2), pp. 267-283. https://doi.org/10.14214/sf.256

5. Laitila, J., Asikainen, A., Nuutinen, Y. 2007 Forwarding of whole trees after manual and mechanized felling bunching in precommercial thinnings. International Journal of Forest Engineering, Vol. 18(2), pp. 29-39.

6. Lazdiņš, A.. 2014. Plastmasas k̦ēžu pielietošanas izmēgeinājumi kokmateriālu pievešanā krājas kopšanā. (Testing of plastic chains in forwarding operations in thinning), LSFRI Silava, Salaspils. [In Latvian]

7. Liepa, I., Miezīte, O., Luguza, S., Šulcs, V., Straupe, I., Indriksons, A., Dubrovskis, D. 2014. Meža tipoloǵija. (Typology of forest) Jalgava. Available at: http://www.mf.llu.lv/getfile.php?id=1052 [In Latvian]

8. Nurminen, T., Korpunen, H., \& Uusitalo, J. 2006. Time Consumption Analysis of Harvesting System. Silva Fennica, Vol. 40(2), pp. 335-363. https://doi.org/10.14214/sf.346

9. Sakai, H., Nordfjell, T., Suadicani, K., Talbot, B., Bøllehuus, E. 2008. Soil compaction on forest soils from different kinds of tires and tracks and possibility of accurate estimate. Croatian Journal of Forest Engineering, Vol. 29(1), pp. 15-27.

10. Sarmulis, Z., Saveljevs, A. 2015. Meža darbi un tehnologijas. (Forest operations and Technologies) Jelgava: Studentu biedrība "Šalkone." Available at: http://www.mf.llu.lv/getfile.php?id=2297 [In Latvian]

11. Sirén, M. 2003. Productivity and Costs of Thinning Harvesters and Harvester-Forwarders. International Journal of Forest Engineering, Vol. 14, pp. 39-48.

12. Strandgard, M., Mitchell, R., Acuna, M. 2017. Time consumption and productivity of a forwarder operating on a slope in a cutto-length harvest system in a. Journal of Forest Science, 2017(7), 324-330. https://doi.org/10.17221/10/2017-JFS

13. Talbot, B., Nordfjell, T., Suadicani, K. 2003. Assessing the Utility of Two Integrated Harvester-Forwarder Machine Concepts Through Stand-Level Simulation. International Journal of Forest Engineering, Vol. 14(2), pp. 31-43. https://doi.org/10.1080/14942119.2003.10702476

14. Uusitalo, J. 2010. Introduction to forest operations and technology.

15. Väätäinen, K., Ala-Fossi, A., Nuutinen, Y., Röser, D. 2006. The Effect of Single Grip Harvester's Log Bunching on Forwarder Efficiency. Baltic-Forestry, Vol. 12(1), pp. 64-69.

16. Zimelis, A., Lazdinš̌, A., Prindulis, U. 2015. Vimek harvestera 404 T5 un pievedējtraktora 610 ražīgums jaunaudžu kopšanā Zviedrijā. (Prouctivity of Vimek 404 T5 harvester and Vimek 610 forwarder in pre-commercial thinning in Sweden), LSFRI Silava, Salaspils. [In Latvian]

17. Zimelis, A., Lazdin̦šs, A., Spalva, G. 2016. Vimek harvestera darba ražīgums bērza plantācijās. (Productivity of Vimek harvester in birch plantations), LSFRI Silava, Salaspils. [In Latvian] 